\title{
First record of Pleurerythrops secundus (Crustacea, Mysida) in association with benthic hydroids (Cnidaria, Hydrozoa) in shallow waters of Izu-Ohshima, Pacific coast of central Japan
}

\author{
Nobuhiro Saito, Osamu Hoshino, Kouki Fukuoka
}

\begin{abstract}
The erythropini mysid, Pleurerythrops secundus Murano, 1970, is recorded in shallow waters of the northeastern coast of Izu-Ohshima Island, Pacific coast of central Japan. Underwater surveys at a depth of 15-30 m by a scuba diver revealed that $P$. secundus lived on the benthic hydroids Aglaophenia whiteleggei Bale, 1888, Dentitheca hertwigi (Stechow, 1909), Gymnangium hians (Busk, 1852), Plumularia habereri Stechow, 1909, and several unidentified hydroid species. This finding represents the first evidence of $P$. secundus associated with benthic organisms. Furthermore, to the best of our knowledge, this is the first report of a mysid species in association with hydrozoans.
\end{abstract}

Key words: coloration, Erythropini, Peracarida, shallow waters, symbiosis, underwater observations

Mysid crustaceans are members of marine zooplankton (Mauchline, 1980). Some species live in association with benthic invertebrates such as sponges, sea anemones, corals, and hermit crabs, although most are free-living and inhabit the near-bottom layer (Mauchline, 1980; Fukuoka, 2004). The second author, OH, has made several new records of small marine animals by underwater observation during scuba diving (Uyeno \& Nagasawa, 2010, 2012; Saito \& Hoshino, 2011, 2015, 2017; Ota et al., 2012; Saito, 2012, 2015; Yamada \& Hoshino, 2014; Saito et al., 2014; Uyeno, 2015; Hoshino \& Saito, 2016; Shimomura, 2016, 2017; Shimomura \& Hoshino, 2017; Okuno, 2017). Recently, he found mysids attached to several species of hydroids (Cnidaria). Herein, we report the association and behavior of mysids and hydroids.

Mysids on hydroids were observed in shallow waters off "Aki-no-hama” (344ㄱ' $14^{\prime}$ N $\left.139^{\circ} 24^{\prime} 32^{\prime \prime} \mathrm{E}\right)$, the northeastern coast of IzuOhshima Island, Pacific coast of central Japan. Surveys were conducted at a depth of 15-30 m almost every day by scuba diving from March
2015 to August 2017 (Table 1). The water temperature in the bottom layer ranged from approximately $13.0^{\circ} \mathrm{C}$ to $27.0^{\circ} \mathrm{C}$. Colonies of hydroids were investigated for attached mysids at 10 sites per day; a total of 23 sites were surveyed during the study period. Mysids associated with hydroids were photographed with an underwater camera set (camera, Nikon D810; camera lens, Nikon AF Micro Nikkor 105 mm; camera housing, Nexus D810). The number of mysid individuals was counted using the photographic records. For taxonomic identification, several individuals were collected, frozen temporally in the laboratory, and then preserved in $70 \%$ ethanol. Morphological observations and measurements were made with the aid of a binocular microscope (Olympus X-II) and a compound microscope (Olympus BHB$\mathrm{Tr})$. Body length (BL) was measured from the tip of the rostrum to the posterior end of the telson, excluding spiniform setae, along the dorsal mid line. Other measurements and terminology followed those of Murano (1997). The examined specimens were deposited in the National Museum of Nature and Science 
Table 1. Occurrence of Pleurerythrops secundus in association with hydroids in the shallow water of Izu-Ohshima Island from March 2015 to August 2017.

\begin{tabular}{|c|c|c|c|c|c|c|c|}
\hline \multirow[b]{2}{*}{ Year } & \multirow[b]{2}{*}{ Month } & \multicolumn{2}{|c|}{ Number of days } & \multirow{2}{*}{$\begin{array}{l}\text { Number of sites } \\
\text { that mysids } \\
\text { occurred }\end{array}$} & \multirow{2}{*}{$\begin{array}{l}\text { Individuals/ } \\
\text { sites }\end{array}$} & \multirow{2}{*}{$\begin{array}{l}\text { Individuals/ } \\
\text { month }\end{array}$} & \multirow[b]{2}{*}{ Hosts } \\
\hline & & Surveyed & $\begin{array}{l}\text { Mysids } \\
\text { occurred }\end{array}$ & & & & \\
\hline \multirow[t]{11}{*}{2015} & March & 29 & 1 & 1 & 1 & 1 & Aglaophenia whiteleggei \\
\hline & April & 28 & 3 & 3 & $1-2$ & 5 & Dentitheca hertwigi \\
\hline & & & & & & & $\begin{array}{l}\text { Gymnangium hians } \\
\text { unidentified hydroids }\end{array}$ \\
\hline & May & 27 & 1 & 1 & 4 & 4 & Aglaophenia whiteleggei \\
\hline & June & 26 & 0 & 0 & 0 & 0 & \\
\hline & July & 28 & 1 & 1 & 1 & 1 & unidentified hydroids \\
\hline & August & 27 & 0 & 0 & 0 & 0 & \\
\hline & September & 23 & 0 & 0 & 0 & 0 & \\
\hline & October & 24 & 0 & 0 & 0 & 0 & \\
\hline & November & 24 & 0 & 0 & 0 & 0 & \\
\hline & December & 28 & 0 & 0 & 0 & 0 & \\
\hline \multirow[t]{12}{*}{2016} & January & 28 & 0 & 0 & 0 & 0 & \\
\hline & February & 24 & 0 & 0 & 0 & 0 & \\
\hline & March & 24 & 0 & 0 & 0 & 0 & \\
\hline & April & 27 & 0 & 0 & 0 & 0 & \\
\hline & May & 27 & 0 & 0 & 0 & 0 & \\
\hline & June & 27 & 0 & 0 & 0 & 0 & \\
\hline & July & 30 & 0 & 0 & 0 & 0 & \\
\hline & August & 22 & 0 & 0 & 0 & 0 & \\
\hline & September & 27 & 0 & 0 & 0 & 0 & \\
\hline & October & 24 & 0 & 0 & 0 & 0 & \\
\hline & November & 23 & 0 & 0 & 0 & 0 & \\
\hline & December & 25 & 1 & 1 & 1 & 1 & unidentified hydroids \\
\hline \multirow[t]{8}{*}{2017} & January & 21 & 1 & 1 & 1 & 1 & Gymnangium hians \\
\hline & February & 24 & 1 & 1 & 1 & 1 & Dentitheca hertwigi \\
\hline & March & 25 & 0 & 0 & 0 & 0 & \\
\hline & April & 24 & 8 & 6 & $1-3$ & 21 & $\begin{array}{l}\text { Dentitheca hertwigi } \\
\text { Plumularia habereri } \\
\text { unidentified hydroids }\end{array}$ \\
\hline & May & 31 & 9 & 4 & $1-8$ & 38 & $\begin{array}{l}\text { Dentitheca hertwigi } \\
\text { unidentified hydroids }\end{array}$ \\
\hline & June & 29 & 7 & 7 & $1-4$ & 13 & $\begin{array}{l}\text { Dentitheca hertwigi } \\
\text { unidentified hydroids }\end{array}$ \\
\hline & July & 30 & 8 & 6 & $1-8$ & 21 & $\begin{array}{l}\text { Dentitheca hertwigi } \\
\text { Plumularia habereri } \\
\text { unidentified hydroids }\end{array}$ \\
\hline & August & 28 & 6 & 3 & $1-1$ & 6 & unidentified hydroids \\
\hline
\end{tabular}

(NSMT), Tsukuba, Japan.

In the present study, two specimens, one male (3.91 mm BL, NSMT-Cr 25855) and one ovigerous female $(3.88 \mathrm{~mm}$ BL, NSMT-Cr 25856) (Fig. 1A, B), were examined in the laboratory. Morphological characteristics of both the specimens were consistent with those of Pleurerythrops secundus Murano, 1970 (Mysidae, Erythropinae, Erythropini): 1) the endopod of pleopod 5 longer than the exopod in male, and with a modified naked stout setae subequal to the length of endopod on the ultimate and 


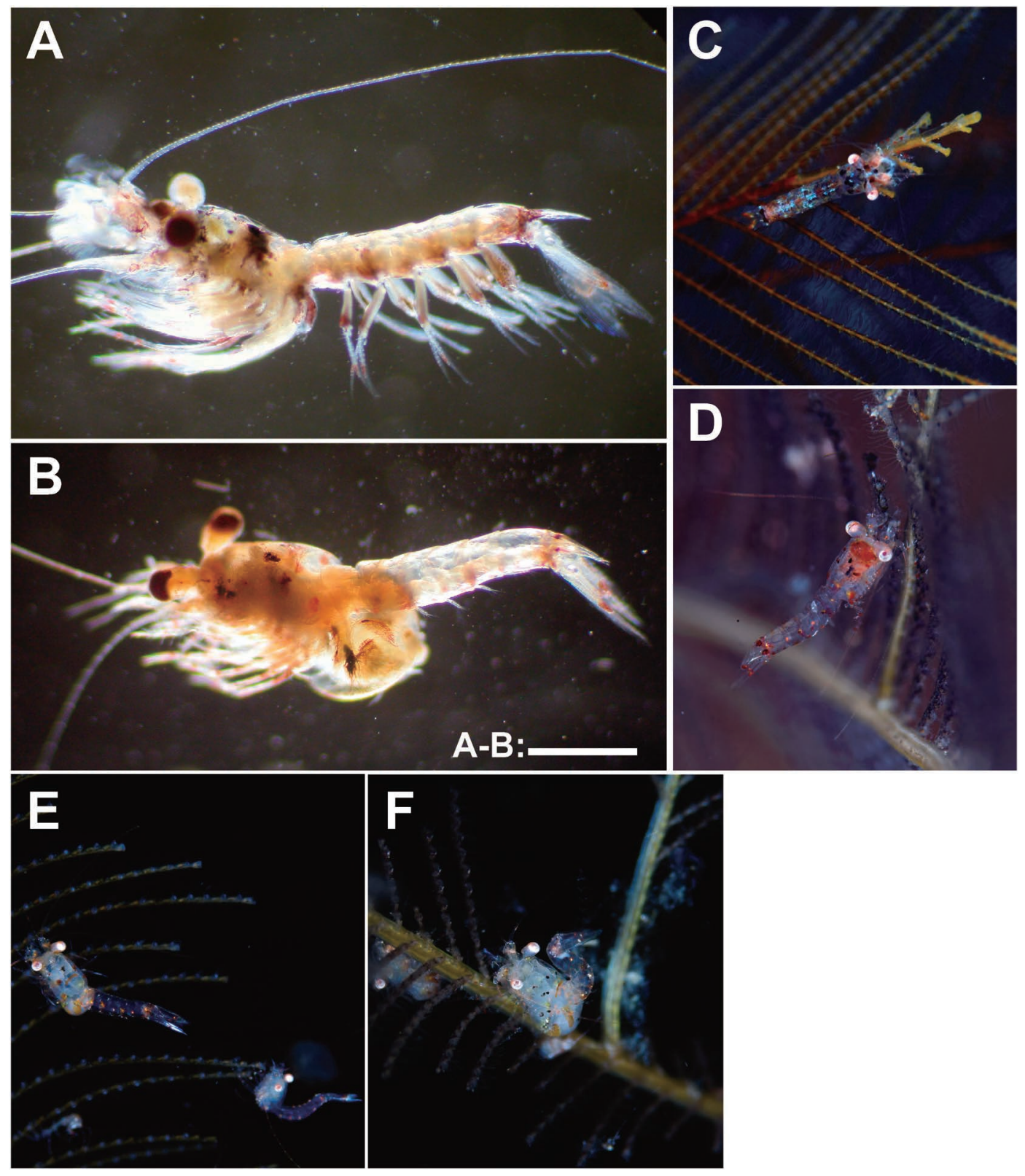

Fig. 1. Pleurerythrops secundus attached to some hydroid species in shallow water off "Aki-no-hama", Izu-Ohshima, Pacific coast of central Japan. A, C, male (3.91 mm BL), NSMT-Cr 25855, 13 January 2017, 25 m depth, host: Gymnangium hians; B, E, ovigerous female (3.88 mm BL), NSMT-Cr 25856, 8 June 2017, $25 \mathrm{~m}$ depth, host: Dentitheca hertwigi; D, a specimen, 20 April 2017, 26 m depth, host: D. hertwigi; F, a specimen, 16 July 2017, $27 \mathrm{~m}$ depth, host: $D$. hertwigi. Scale bar $=1 \mathrm{~mm}$.

penultimate segments and 2) the inner pair of spiniform setae on the narrow apex of telson straight and slender. Pleurerythrops secundus has been recorded from Suruga Bay (Murano, 1970, 1981), the Ariake Sea (Murano, 1981),
Omura Bay (Murano, 1981), and the East China Sea (Murano, 1981). Therefore, the present occurrence of $P$. secundus slightly extends the distributional range of this species eastward.

The genus Pleurerythrops comprises five 
species, P. americanus Zoppi de Roa \& Delgado, 1989, P. constrictus Panampunnayil, 1977, P. inscitus Ii, 1964, P. monospinosus Liu \& Wang, 1986, and P. secundus (Mees \& Meland, 2012), although the affiliation of $P$. americanus is doubtful. The coloration of the Pleurerythrops species has not been recorded previously. This might be due to the examination of preserved specimens in fixatives. For the first time, in the present study, we revealed the coloration of $P$. secundus by observing live individuals. Live $P$. secundus is transparent with light brown chromatophores (Fig. 1): brown spots on carapace and female oostegites; dark brown endopods of thoracopods, posterior end of sixth pleonite, basal part of telson, tip of uropodal peduncle, distal end of uropod, and male penis. Cornea of the eye is black.

In the present field observations, $P$. secundus occurred from March to July 2015 and from December 2016 to August 2017 (Table 1). This species was found on the following hydroids: Aglaophenia whiteleggei Bale, 1888, Dentitheca hertwigi (Stechow, 1909), Gymnangium hians (Busk, 1852), Plumularia habereri Stechow, 1909, and several unidentified species. The mysids were observed on 47 days at 23 sites with hydroid colonies covering a total area of approximately $6800 \mathrm{~m}^{2}$. One to eight individuals were attached to a hydroid branch (hydrocaulus) via the thoracic endopods. When disturbed, individuals moved quickly for some distance along a hydroid branch. In some cases, several mysid individuals attached to the

Table 2. Records of mysid species in association with cnidarians except corals.

\begin{tabular}{|c|c|c|c|}
\hline Species & & Host & Literature \\
\hline \multicolumn{4}{|l|}{ Heteromysinae } \\
\hline \multirow[t]{4}{*}{ Heteromysis actiniae } & sea anemone & Bartholomea annulata & Clarke (1955); \\
\hline & & & Brattegard $(1969,1974,1975)$; \\
\hline & & & Modlin (1987) \\
\hline & sea anemone & unknown & Brattegard (1970) \\
\hline Heteromysis bermudensis & sea anemone & Bartholomea annulata & Clarke (1955) \\
\hline \multirow[t]{2}{*}{ Heteromysis mayana } & sea anemone & Bartholomea annulata & Modlin (1987) \\
\hline & sea anemone & unknown & Brattegard (1970) \\
\hline Heteromysis wirtzi & sea anemone & Telmatactis cricoides & Wittmann (2008) \\
\hline Ischiomysis telmatactiphila & sea anemone & Telmatactis cricoides & Wittmann (2013) \\
\hline Ischiomysis peterwirtzi & sea anemone & Telmatactis cricoides & Wittmann (2013) \\
\hline \multicolumn{4}{|l|}{ Leptomysinae } \\
\hline Leptomysis truncata pontica & sea anemone & Anemonia sulcata & Wittmann (1978) \\
\hline Leptomysis truncata truncata & sea anemone & Anemonia sulcata & Wittmann (1986) \\
\hline Leptomysis truncata sardica & sea anemone & Anemonia sulcata & Wittmann $(1978 ; 1986)$ \\
\hline Leptomysis buergii & sea anemone & Anemonia sulcata & Wittmann (1986) \\
\hline Leptomysis lingvura adriatica & sea anemone & Anemonia sulcata & Wittmann (1986) \\
\hline Leptomysis lingvura lingvura & sea anemone & Anemonia sulcata, Aiptasia mutabilis & Wittmann (1978) \\
\hline Metamysidopsis elongata & medusa & Chrysaora achlyos & Martin \& Kuck (1991) \\
\hline Mysidopsis cathengelae & medusa & Chrysaora achlyos & Martin \& Kuck (1991) \\
\hline Pyroleptomysis rubra & sea anemone & Anemonia sulcata & Wittmann (1978) \\
\hline \multicolumn{4}{|l|}{ Mysidellinae } \\
\hline Mysidella hoshinoi & sea anemone & Haloclavidae sp. & Shimomura (2016) \\
\hline \multicolumn{4}{|l|}{ Mysinae } \\
\hline Idiomysis inermis & sea anemone & Stichodactyla haddoni & $\begin{array}{l}\text { Greenwood \& Hadley (1982); } \\
\text { Bhaduri \& Crowther (2016) }\end{array}$ \\
\hline \multirow[t]{2}{*}{ Idiomysis tsurnamali } & sea anemone & Megalactis hemprichii & Bacescu (1973) \\
\hline & medusa & Cassiopea andromeda & Bacescu (1973) \\
\hline
\end{tabular}


branch of hydroids decreased in number or disappeared on the subsequent observation day. Other invertebrates such as pycnogonids (Nymphopsis muscosa Loman, 1908), copepods, amphipods (Microjassa sp. and Caprella californica Stimpson, 1856), and decapods (Rapipontonia galene (Holthuis, 1952)) co-occurred on the hydroids in the observation sites (H. Ariyama, M. Aoki, K. Miyazaki, personal communications for taxonomic identifications).

Eighteen mysid species and subspecies belonging to the subfamilies Heteromysinae, Leptomysinae, Mysidellinae, and Mysinae were recorded in association with various cnidarians, except corals (Table 2). Most of these species are associated with sea anemones. Furthermore, Idiomysis tsurnamali Bacescu, 1973 was observed hovering over the scyphozoan medusa Cassiopea andromeda (Forsskål, 1775) (Bacescu, 1973). Martin \& Kuck (1991) also reported two species, Metamysidopsis elongata (Holmes, 1900) and Mysidopsis cathengelae Gleye, 1982, from the washing of the scyphozoan medusa Chrysaora achlyos Martin, Gershwin, Burnett, Cargo \& Bloom, 1997 collected from inshore water, although it was not clear whether the occurrence was due to symbiosis or contingency. To the best of our knowledge, the present study is the first report of mysids associated with hydroids. Most mysid associates of cnidarians form a loose relationship with their host species, swimming around the body of the host without contacting it (Bacescu, 1973; Greenwood \& Hadley, 1982; Wittmann, 1986, 2008, 2013; Bhaduri \& Crowther, 2016). Heteromysis actiniae Clarke, 1955 and Mysidella hoshinoi Shimomura, 2016, mysid symbionts of the sea anemone Bartholomea annulata (Le Sueur, 1817) and unidentified species of Haloclavidae, respectively (Clarke, 1955; Brattegard, 1969, 1974, 1975; Modlin, 1987; Shimomura, 2016), settle or sometimes perch on the tentacles (Clarke, 1955; Shimomura, 2016). In the present study, $P$. secundus was usually found attached to branches of hydroids when observed underwater.
Pleurerythrops secundus was collected from near-bottom layers at depths of $28-240 \mathrm{~m}$ by beam-trawl, bottom-net, and sledge (Murano, 1970, 1981); however, it is not known whether this mysid species lives in contact with bottom sediments and benthic organisms. The present finding by underwater observation is the first record of $P$. secundus in association with hydroids.

\section{Acknowledgments}

We thank Drs. Hiroyuki Ariyama (Osaka Museum of Natural History), Masakazu N. Aoki (Tohoku University), and Katsumi Miyazaki (Niigata University), for identification of co-occurring marine animals. We sincerely thank Dr. Kaori Wakabayashi (Hiroshima University) for making helpful suggestions concerning early drafts of this paper. Thanks are also extended to two anonymous reviewers for their useful comments on this manuscript.

\section{$\square$ Literature Cited}

Bacescu, M., 1973. A new case of commensalism in the Red Sea: the mysid Idiomysis tsurnamali $\mathrm{n}$. sp. with the Coelenterata Megalactis and Cassiopea. Revue Roumaine de Biologie - Zoologie, 18: 3-7.

Bhaduri, R. N., \& Crowther, A. L., 2016. Association of the mysid Idiomysis inermis with the sea anemone Stichodactyla haddoni in Moreton Bay, Australia. Marine Biodiversity, 46: 707-711.

Brattegard, T., 1969. Marine biological investigations in the Bahamas 10, Mysidacea from shallow water in the Bahamas and southern Florida, part 1. Sarsia, 39: 17-106.

Brattegard, T., 1970. Mysidacea from shallow water in the Caribbean Sea. Sarsia, 43: 111154.

Brattegard, T., 1974. Mysidacea from shallow water on the Caribbean coast of Panama. Sarsia, 57: 87-108.

Brattegard, T., 1975. Shallow-water Mysidacea 
from the Lesser Antilles and other Caribbean regions. Studies on the Fauna of Curaçao and other Caribbean Islands, 47: 102-115.

Clarke, W. D., 1955. A new species of the genus Heteromysis (Crustacea, Mysidacea) from the Bahama Islands, commensal with a seaanemone. American Museum Novitates, 1716: 1-13.

Fukuoka, K., 2004. A new species of Heteromysis (Mysida, Mysidae) associated with sponges, from the Uraga Channel, central Japan, with notes on distribution and habitats within the genus Heteromysis. Crustaceana, 77: 13531373.

Greenwood, J. G., \& Hadley, D. J., 1982. A redescription of the mysid Idiomysis inermis Tattersall, 1922 (Mysidacea) to include the previously unknown female. Crustaceana, 42: 174-178.

Hoshino, O., \& Saito, N., 2016. Note on a SCUBA observation in a field of mother-young association of an arcturid isopod. Umiushitsushin, 90: 5. (In Japanese)

Martin, J., \& Kuck, H., 1991. Faunal associates of an undescribed species of Chrysaora (Cnidaria, Scyphozoa) in the Southern California Bight, with notes on unusual occurrences of other warm water species in the area. Bulletin of the Southern California Academy of Sciences, 90: 89-101.

Mauchline, J., 1980. The biology of mysids. Advances in Marine Biology, 18: 1-369.

Mees, J., \& Meland, K. (Eds.), 2012 onwards. World List of Lophogastrida, Stygiomysida and Mysida. Erythropini Hansen, 1910. Accessed through: World Register of Marine Species at: http://marinespecies.org/aphia. php? $p=$ taxdetails\&id=148709 on 2018-04-12

Modlin, R. F., 1987. Mysidacea from shallow waters in the vicinity of Carrie Bow Cay, Belize, Central America, with descriptions of two new species. Journal of Crustacean Biology, 7: 106-121.

Murano, M., 1970. A small collection of benthic Mysidacea from coastal waters in Suruga Bay, Japan. Crustaceana, 18: 251-268.
Murano, M., 1981. Mysidacea from the central and western Pacific. V. Genera Heteroerythrops, Meierythrops, Pleurerythrops, Gibberythrops, Illigiella, Dactylamblyops, Pseudamblyops, Paramblyops, Dactylerythrops and Nakazawaia (tribe Erythropini). Publications of the Seto Marine Biological Laboratory. 26: 261-302.

Murano, M., 1997. Mysidacea. In Chihara, M, \& Murano, M. (eds.), An illustrated guide to marine plankton in Japan, pp.xiv-xv + 1010-1084. Tokai Univ. Press., Tokyo. (In Japanese)

Okuno, J., 2017. Designation of a new genus Michaelimenes (Decapoda: Caridea: Palaemonidae), with new host record and range extension of its type species, M. perlucidus (Bruce, 1969). Nauplius, 25: 1-12.

Ota, Y., Hoshino, O., Hirose, M., Tanaka, K., \& Hirose, E., 2012. Third-stage larva shifts host fish from teleost to elasmobranch in the temporary parasitic isopod, Gnathia trimaculata (Crustacea; Gnathiidae). Marine Biology, 159: 2333-2347.

Saito, N., 2012. A new species of cirolanid isopod, Eurydice nunomurai (Crustacea) from Izu-Ohshima Island, Sagami Sea, Pacific coast of central Japan. Crustacean Research, 41: 19-25.

Saito, N., 2015. A new hemiarthrine bopyrid, Izuohshimaphryxus hoshinoi (Crustacea: Isopoda) from Izu-Ohshima Island, Sagami Sea, Pacific coast of central Japan. Crustacean Research, 44: 67-73.

Saito, N., \& Hoshino, O., 2011. Ecological notes on the infaunal mysid, Heteromysis komaii Fukuoka, 2004 (Crustacea: Mysida: Mysidae), associated with sponges Callyspongia confoederata (Ridley, 1884) from IzuOhshima Island, Sagami Sea, central Japan. Natural History Report of Kanagawa, 32: 51-54. (In Japanese with English abstract)

Saito, N., \& Hoshino, O., 2015. Descriptions of immature stages of Cymothoidae (Crustacea: Isopoda) collected from Izu-Ohshima, Pacific coast of central Japan. Cancer, 24: 53-62. 
(In Japanese with English abstract)

Saito, N., \& Hoshino, O., 2017. Record of Cymothoidae (Crustacea: Isopoda) infecting buccal cavity of Trimma okinawae collected from Izu-Ohshima, Japan. Cancer, 26: 2124. (In Japanese)

Saito, N., Yamauchi, T., Ariyama, H., \& Hoshino, O., 2014. Descriptions and ecological notes of free-swimming forms of cymothoid isopods (Crustacea: Peracarida) collected in two waters of Japan. Crustacean Research, 43: $1-16$.

Shimomura, M., 2016. Mysidella hoshinoi, a new species from Izu-Oshima Island, Japan (Crustacea, Mysidae, Mysidellinae). ZooKeys, 620: 21-32.

Shimomura, M., 2017. A new species of Aspidophryxus (Isopoda, Dajidae), ectoparasitic on Mysidella hoshinoi (Mysidae) in Japan. ZooKeys, 646: 109-118.

Shimomura, M., \& Hoshino, O., 2017. Field observation of the ectoparasitic isopod Aspidophryxus izuensis Shimomura, 2017 (Dajidae) in Izu-Oshima Island. Cancer, 26: 25-30. (In Japanese)

Uyeno, D., 2015. Systematic revision of the pennellid genus Creopelates Shiino, 1958 (Copepoda: Siphonostomatoida) and the proposal of a new genus. Zootaxa, 3904: 359-386.

Uyeno, D., \& Nagasawa, K., 2010. Three new species of the family Pennellidae (Copepoda: Siphonostomatoida) from gobiid fishes (Actinopterygii: Perciformes) in coastal waters of the western Pacific Ocean. Zootaxa, 2687: 29-44.

Uyeno, D., \& Nagasawa, K., 2012. Ttetaloia hoshinoi, a new genus and species of chondracanthid copepod (Poecilostomatoida) parasitic on triplefins (Actinopterygii: Tripterygiidae) from Japanese waters. Zoosymposia, 8: 39-48.

Wittmann, K. J., 1978. Biotop- und Standortbindung meditettaner Mysidacea. 211 pp. Dissertation zur Erlangung des Doktorgrades an der Formal- und Naturwissenschaftlichen Fakultät der Universität Wien.
Wittmann, K. J., 1986. Untersuchungen zur Lebensweise und Systematik von Leptomysis truncata und zwei verwandten Formen (Crustacea, Mysidacae). Annalen des Naturhistorischen Museums in Wien, 87B: 295-323, Taf. 1.

Wittmann, K. J., 2008. Two new species of Heteromysini (Mysida, Mysidae) from the island of Madeira (N.E. Atlantic), with notes on sea anemone and hermit crab commensalisms in the genus Heteromysis S. I. Smith, 1873. Crustaceana, 81: 351-374.

Wittmann, K. J., 2013. Mysids associated with sea anemones from the tropical Atlantic: Description of Ischiomysis new genus, and two new species in this taxon (Mysida, Mysidae, Heteromysinae). Crustaceana, 86: 487-506.

Yamada, K., \& Hoshino, O., 2014. Esperiopsis plumosa Tanita 1965 (Esperiopsidae, Demospongiae) declined by a commensal polychaete Polydorella dawydoffi Radashevsky 1996 (Spionidae), Izu Oshima Island, Japan. Bulletin of the Biogeographical Society of Japan, 69: 189-191. (In Japanese with English abstract)

\section{Addresses:}

(NS) Suido-sha Co. Ltd., Ikuta 8-11-11, Tamaku, Kawasaki, Kanagawa 214-0038, Japan; $(\mathrm{OH})$ Diving Services Chap, Okatashinkai 118-2, Ohshima, Tokyo 100-0102, Japan; (KF) Seikai National Fisheries Research Institute, Japan Fisheries Research and Education Agency, Taira 1551-8, Nagasaki, Nagasaki 851-2213, Japan.

\section{E-mail addresses:}

(NS)nsaitoh@suidosha.co.jp. Corresponding author

(OH) hossy@chap.jp

(KF) fukuokak@fra.affrc.go.jp 